Article

\title{
Assessing the Self-Purification Capacity of Surface Waters in Lake Baikal Watershed
}

\author{
Mikhail Yu. Semenov ${ }^{1, *}$, Yuri M. Semenov ${ }^{2}$, Anton V. Silaev ${ }^{2}$ and Larisa A. Begunova ${ }^{3}$ \\ 1 Limnological Institute of Siberian Branch of Russian Academy of Sciences, Ulan-Batorskaya St. 3, \\ 664033 Irkutsk, Russia \\ 2 V.B. Sochava Institute of Geography of Siberian Branch of Russian Academy of Sciences, \\ Ulan-Batorskaya St. 1, 664033 Irkutsk, Russia \\ 3 Irkutsk National Research Technical University, Lermontov St. 83, 664074 Irkutsk, Russia \\ * Correspondence: smu@mail.ru
}

Received: 9 May 2019; Accepted: 17 July 2019; Published: 20 July 2019

Abstract: The removal of trace metals (TM), dissolved organic carbon (DOC), mineral nitrogen $\left(\mathrm{N}_{\mathrm{min}}\right.$.), and polycyclic aromatic hydrocarbons (PAHs) from the water of Lake Baikal and its tributaries was evaluated. The contaminant removal rate (CRR) and the contaminant removal capacity (CRC) were used as water self-purification parameters. The CRR was calculated as the difference between contaminant mass flow rates at downstream and upstream gauging stations. The CRC was calculated as the quotient of the CRR and the change in water discharge between downstream and upstream gauging stations. Whether the CRR and CRC have positive or negative values depends on whether contaminant release or removal occurs in the water body. The CRR depends on the size of the water body. The lowest and the highest CRRs observed for Baikal were equal to $-15 \mathrm{mg} / \mathrm{s}$ (PAHs) to $-7327 \mathrm{~g} / \mathrm{s}$ (DOC), whereas the highest PAH and DOC removal rates observed for Selenga River (the major Baikal tributary) in summer were equal to $-9 \mathrm{mg} / \mathrm{s}$ and $-3190 \mathrm{~g} / \mathrm{s}$ correspondingly. The highest PAH and DOC removal rates observed for small tributaries were equal to $0.0004 \mathrm{mg} / \mathrm{s}$ and $-0.7 \mathrm{~g} / \mathrm{s}$ respectively. The amplitude of annual CRR oscillations depends on contaminant abundance. The highest amplitude was typical for most abundant contaminants such as $\mathrm{N}_{\min }$ and DOC. In unpolluted sections of the Selenga River the highest rates of $\mathrm{N}$ and C removal $(-85 \mathrm{~g} / \mathrm{s}$ and $-3190 \mathrm{~g} / \mathrm{s}$, respectively) were observed in summer and the lowest rates $(4 \mathrm{~g} / \mathrm{s}$ and $3869 \mathrm{~g} / \mathrm{s}$, respectively) were observed in the spring. The lowest amplitude was typical for PAHs and some low-abundance TM such as $\mathrm{V}$ and $\mathrm{Ni}$. The highest summer rates of $\mathrm{V}$ and $\mathrm{Ni}$ removal were equal to $-378 \mathrm{mg} / \mathrm{s}$ and $-155 \mathrm{mg} / \mathrm{s}$ respectively, whereas lowest spring rates are equal to $296 \mathrm{mg} / \mathrm{s}$ and $220 \mathrm{mg} / \mathrm{s}$. The intermediate CRR amplitudes were typical for most abundant TM such as $\mathrm{Sr}, \mathrm{Al}$, and Fe. The spatial CRR variability depends on water chemistry and the presence of pollution sources. The lowest (up to $38 \mathrm{~g} / \mathrm{s}$ ) rates of $\mathrm{N}_{\min }$. removal was observed for polluted lower Selenga sections characterized by low water mineralization and high DOC concentrations. The highest rates $(-85 \mathrm{~g} / \mathrm{s})$ were observed for unpolluted upper sections. Seepage loss from the river to groundwater was also recognized as an important means of contaminant removal. The CRC values depend mostly on water residence time. The DOC removing capacity value of Baikal $\left(-26 \mathrm{~g} / \mathrm{m}^{3}\right)$ were lower than those of Selenga in summer $\left(-35 \mathrm{~g} / \mathrm{m}^{3}\right)$ but higher than the CRCs of all tributaries during the other seasons (from $30 \mathrm{mg} / \mathrm{m}^{3}$ to $-10 \mathrm{~g} / \mathrm{m}^{3}$ ).

Keywords: Baikal; self-purification capacity; trace metals; organic carbon; mineral nitrogen; polycyclic aromatic hydrocarbons

\section{Introduction}

Lake Baikal, a UNESCO World Heritage Site, is the largest freshwater lake by volume in the world, containing roughly $20 \%$ of the world's unfrozen surface freshwater. Moreover, it is the source 
of drinking water for thousands of villages and towns located around the lake and along the Angara River-the only outflow of Lake Baikal. To ensure the preservation of the lake's ecosystem and the quality of the water flowing downstream, the evaluation of the self-purification capacity of the lake and its tributaries is necessary. However, the self-purification capacity of water bodies in the Lake Baikal watershed has not been previously assessed. The absence of such estimates is conditioned by the absence of significant effects of environmental pollution on aquatic biota and water quality [1,2], although some signs of water pollution (unpleasant odors, unchecked growth of aquatic weeds, etc.) in Lake Baikal have appeared in the last decade [3,4]. Even though the anthropogenic origin of changes in lake environment has not yet been proved [5], the need to evaluate the self-purification capacity of natural water systems has become evident.

Despite the absence of direct estimations of self-purification capacity, numerous hydrological and hydrochemical studies conducted within the past few decades have been related in some way to different aspects of contaminant sequestration processes in riverine and lake waters. In particular, the evaluation of suspended sediment removal and bed load discharge in the Selenga River [6] and its delta [7,8] could be regarded as an assessment of river purification from particulate matter. The sustainability of rivers despite anthropogenic impact was assessed to some extent using the morphometric and hydro-meteorological characteristics of river basins [9]. The results of some studies on the chemical composition of riverine and lake water can be treated as qualitative estimates of water purification from dissolved contaminants. For example, the decrease in macro and trace element concentration from the source to the mouth of the Selenga River can be interpreted as element sequestration due to dilution [10-14]. The different concentrations of biogenic elements [14,15] and heavy metals [16] in different channels of the Selenga River delta can be regarded as different self-purification capacities of the water in those channels, and changes in the concentration of solutes along the channels can be interpreted as changes in self-purification capacity.

The residence time of any element in Lake Baikal's water can be considered the rate of water self-purification with respect to a contaminant $[17,18]$. Additionally, the self-purification of lake water with respect to biogenic elements [19] and heavy metals [20] can be assessed on the basis of changes in their concentrations in the water and suspended sediments with increasing distance from the Selenga delta. Organic matter (OM) sequestration in the lake results in qualitative and quantitative composition changes in waterborne polycyclic aromatic hydrocarbons (PAHs) in the onshore-offshore direction [21,22]. One mechanism of water purification from organic solutes such as $\mathrm{PAH}$ and $\mathrm{OM}$ is microbial degradation [22]. Its involvement in the purification of Baikal water in the littoral zone has been confirmed by the positive correlation between the abundance of microorganisms in epilithic biofilms formed on stony substrates and anthropogenic load [23]. The net balance between the decomposition and production of organic matter in Baikal (including organic contaminants) has been assessed in terms of $\mathrm{O}_{2}$ and $\mathrm{CO}_{2}$ emission and absorption values [24-26]. The only quantitative measure that has been used to evaluate surface water purification from dissolved contaminants in the Baikal watershed is biological oxygen demand (BOD) — the amount of oxygen consumed by bacteria in the process of organic matter decomposition [19]. However, BOD does not reflect natural conditions since the final $\mathrm{O}$ concentration measurement in the BOD test is made after water is incubated for 5 days in dark sealed bottles at a constant temperature $\left(20^{\circ} \mathrm{C}\right)$.

Outside the Baikal region, quantitative estimates of water purification capacity are widely used. The value of contaminant removal is calculated using parameters of the corresponding purification mechanism; thus, the value of water purification capacity differs among contaminants. For example, water purification from $\mathrm{OM}$ is based on the development and analysis of the oxygen sag curve [27], which represents the temporal development of BOD and dissolved oxygen (DO) concentrations. The removal of heavy metals (HMs) by their complexation with inorganic ligands can be evaluated on the basis of the relationship between the HM concentration in water and salinity [28]. The biochemical removal of nitrogen $(\mathrm{N})$ from lake water can be quantified using water residence time or phosphorus 
concentration $[29,30]$. The removal of $\mathrm{N}$ and $\mathrm{OM}$ from riverine water has also been evaluated using data on microbial density in bottom sediments [31], water salinity, and the value of solar radiation [32].

The primary purpose of such studies has been to prove that contaminant removal via a presumed purification mechanism is possible; however, the purpose should be to find the predominant mechanism of contaminant removal. Moreover, the occurrence of contaminant removal in the natural environment should be established first because the change in concentration of a contaminant does not always mean its removal. From this point of view, the most objective way to evaluate the self-purification capacity of streams, rivers [33], and throughflow lakes [34,35] is to compare the quantity of a contaminant entering and leaving the lake or section of a river between an upstream and downstream location.

The main goal of this study is to evaluate the natural removal of various contaminants from the water of Lake Baikal and its tributaries in terms of the mass of contaminant per volume of water (or per time unit) using the above-mentioned mass balance approach. Another goal is to determine the most probable contaminant removal mechanisms typical for all contaminants. To achieve these goals, two proposed parameters of water self-purification capacity were developed and tested. Since the spatial and temporal variability of water chemistry may vary significantly in time and space [36-39] the water self-purification capacity was assessed in spatial and temporal dimensions.

\section{Materials and Methods}

The study was conducted in the Lake Baikal watershed (Figure 1) in 2015 and 2017. The study area is a mountainous region characterized by a boreal climate and coniferous vegetation. The study area is characterized by long, cold winters lasting 4-5 months (November-March) and short hot summers (June-August). Winter air temperatures reach -37 degrees Celsius $\left({ }^{\circ} \mathrm{C}\right)$, the summer air temperatures are about $25^{\circ} \mathrm{C}$ to $30{ }^{\circ} \mathrm{C}$.

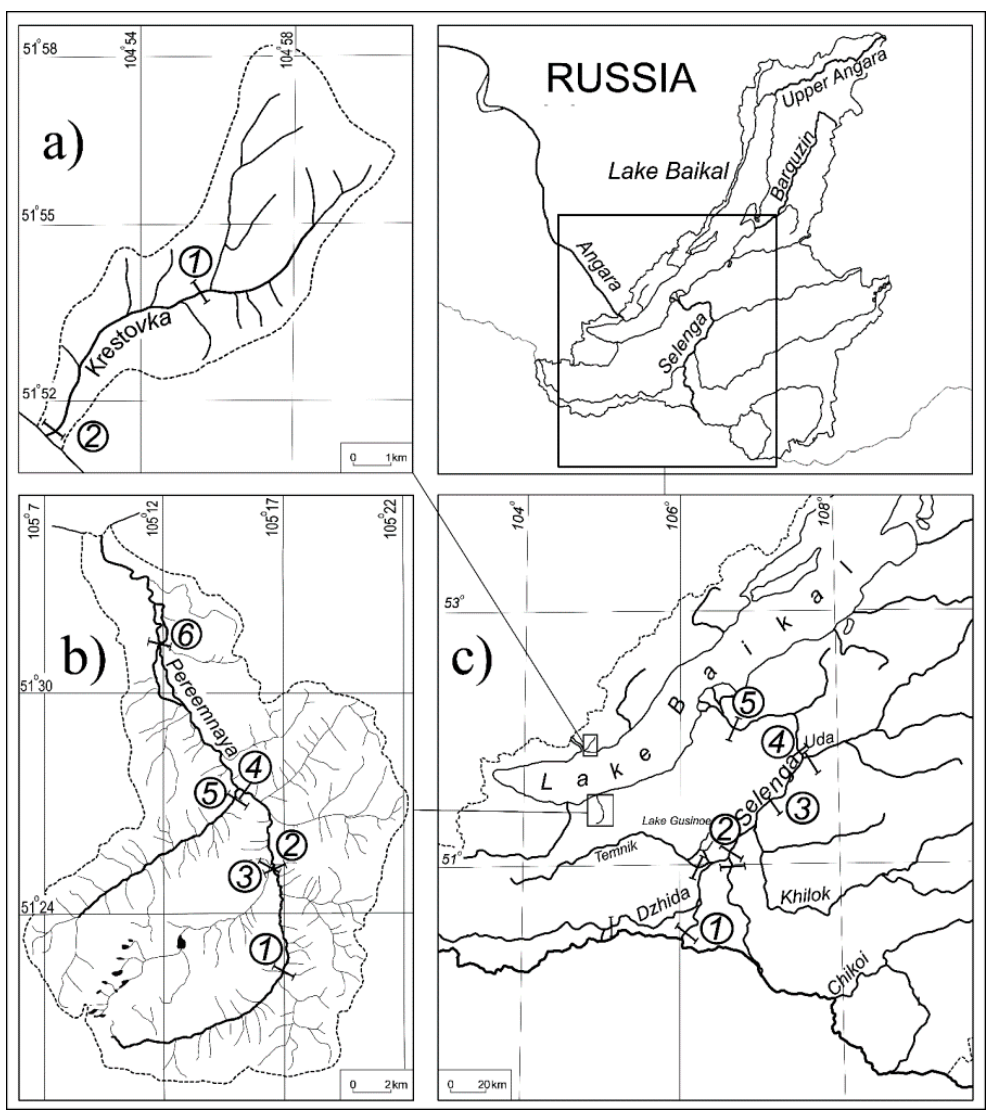

Figure 1. Study area. (a) Krestovka, (b) Pereemnaya, (c) Selenga. 
Spatial variation in precipitation is high across the watershed, with the western coast receiving about $400 \mathrm{~mm}$ of precipitation annually, while as much as 600 to $800 \mathrm{~mm}$ are deposited on the southeastern coast. Extremely high precipitation (up to $1200 \mathrm{~mm} / \mathrm{year}$ ) is observed on northern slopes of Khamar-Daban Ridge located on the southeastern coast of Lake Baikal towards the Angara River, the only Baikal outflow. Most of the precipitation falls in the summer. Lake Baikal and three lake tributaries were investigated. These include the small river Krestovka (Figure 1a) located on the western coast; the small river Pereemnaya (Figure 1b) flowing down the northern side of the Khamar-Daban Ridge located on the eastern coast; and the Selenga river (Figure 1c), the major tributary of Baikal that contributes about $60 \%$ of the surface water inflow into the lake. The number of water sampling stations established on the Selenga, Pereemnaya, and Krestovka rivers were 5, 4, and 2, respectively. Besides the studied rivers, the chemical composition of five Selenga tributaries (rivers Chikoy, Khilok, Uda, Dzhida, and Temnik) was evaluated. Also, data from the literature on the water chemistry of two major Baikal tributaries (rivers Barguzin and Upper Angara) and the authors' data on the chemistry of 75 small southern tributaries were used to calculate Lake Baikal's self-purification capacity. Five sampling stations were established on Selenga tributaries, and two stations were established on Pereemnaya's tributaries, one for each river. Water was sampled quarterly, and about 200 samples were collected in total. The season-averaged contaminant concentrations were used for calculations.

The water self-purification capacity was evaluated in terms of both the rate of removal and the mass of contaminants removed. The rate of contaminant removal from water (CRR) was calculated as the difference between contaminant mass flow rates at downstream and upstream gauging stations:

$$
\mathrm{CRR}, \mathrm{mg} / \mathrm{s}=\mathrm{C}_{2} \times \mathrm{Q}_{2}-\mathrm{C}_{1} \times \mathrm{Q}_{1}
$$

where $C_{2}$ and $C_{1}$ are contaminant concentrations in $\mu \mathrm{g} / \mathrm{L}$ at downstream and upstream gauging stations, respectively; $Q_{2}$ and $Q_{1}$ are water discharges in $\mathrm{m}^{3} / \mathrm{s}$ at downstream and upstream gauging stations, respectively; $C_{1} \times Q_{1}$ may also equal the sum of $C \times Q$ values calculated for the upstream river station and tributary stations located between the downstream and upstream river stations.

Negative CRR values indicate the quantity of contaminants removed from the water (immobilized) every second between two stations, and positive values indicate the quantity of contaminants released into the water (mobilized) during this time. The distance between stations was selected in a way that results in the equal travel time of water between two adjacent stations. This was done to exclude differences in CRR values that arise from different water residence times in different sections of the river.

To compare the self-purification capacities of water in Lake Baikal and the Selenga, Pereemnaya, and Krestovka rivers, the values of contaminant removal capacity (CRC), which represents the quotient of $C R R$ and the change in water discharge $(\Delta Q)$ between downstream and upstream gauging stations, were calculated:

$$
\text { CRC, } \mathrm{mg} / \mathrm{m}^{3}=\left(\mathrm{C}_{2} \times \mathrm{Q}_{2}-\mathrm{C}_{1} \times \mathrm{Q}_{1}\right) /\left(\mathrm{Q}_{2}-\mathrm{Q}_{1}\right)
$$

The CRC is a relative value that indicates the mass of the contaminant removed from (or released to) water per unit of water volume removed from (or released to) river channel and reflects the dependence of the corresponding CRR value on hydrological processes. If negative $\Delta Q$ values arose because the river contributes to groundwater recharge or evaporation, the obtained CRC values were taken with a reversed sign. Otherwise, a correct classification of contaminant removal (negative CRR value) could be erroneously classified as contaminant release (positive CRC value) and vice versa.

Riverine water was sampled from the water surface. The concentrations of PAHs, dissolved organic carbon (DOC), nitrate ions $\left(\mathrm{NO}_{3}{ }^{-}\right), \mathrm{Sr}, \mathrm{Zn}, \mathrm{Cu}, \mathrm{Sn}, \mathrm{Mo}, \mathrm{V}, \mathrm{Ti}, \mathrm{Ni}, \mathrm{Fe}, \mathrm{Mn}, \mathrm{Al}$, and some other metals in the water samples were measured. All dissolved components, except for PAHs, were measured in filtered water. Trace metals were measured using Agilent 7500 mass spectrometer. The ICP-MS was calibrated at six concentration levels $(0.5,1,2,5,10$, and $20 \mu \mathrm{g} / \mathrm{L})$ to determine the linearity of the responses before sample analysis. The linearity of the calibration curve provides accurate estimates of metal concentrations below $0.5 \mu \mathrm{g} / \mathrm{L}$ and above $20 \mu \mathrm{g} / \mathrm{L}$. For the calibration 
of the mass spectrometer the multi-element standard solutions ICP-MS68A-A and ICP-MS-68A-B (High-purity standards, Charleston, USA) were used. To control the analysis quality, all samples were spiked with internal surrogate standards. Since there was no sample manipulation performed before measurement, the recovery of metal analytes was not assessed. Detection limits for trace metals varied from $0.03 \mu \mathrm{g} / \mathrm{L}$ (for Ni and V) to $0.2 \mu \mathrm{g} / \mathrm{L}$ (for Al and Fe). The accuracy (closeness of a measured value to a standard one) and precision (closeness of repeat analysis values) expressed as standard deviation was either excellent $(<3 \%)$ or good $(3-7 \%)$. The DOC concentrations were measured using a Vario TOC Cube Analyzer (Elementar Analysensysteme $\mathrm{GmbH})$. The concentration of $\mathrm{NO}_{3}{ }^{-}\left(\mathrm{N}_{\text {min. }}\right.$. hereinafter) was measured using a Dionex ICS-3000 ion chromatograph. Trace metals were measured using an Agilent 7500 mass spectrometer.

PAHs were measured in unfiltered samples since the PAH concentrations in the surface waters of the Lake Baikal region are extremely low [22]. The samples were analyzed using an Agilent GC/MS system (Santa-Clara, CA 95051, USA) consisting of an Agilent Model 7890B gas chromatograph (GC) and an Agilent Model 5977A mass selective detector (MSD). The GC-MS was calibrated at six concentration levels $(0.04,0.4,1,4,6$, and $10 \mathrm{ng} / \mathrm{L})$. To control the analysis quality, all samples were spiked with $100 \mu \mathrm{L}$ of PAH surrogate standards (EPA 525 Fortification solution B) before extraction. The samples were analyzed using an Agilent GC/MS system consisting of an Agilent Model 6890N gas chromatograph (GC) and an Agilent Model 5973 mass selective detector (MSD). To ensure that the expected levels of quality were reached, detection limits, precision and accuracy of measurements and recovery efficiency of the analytical method were assessed. To assess the recovery, five replicate distilled water samples were spiked with standard solutions and analyzed. The average recovery of PAHs was $99 \pm 11 \%$. The recovery values were calculated as part of the QA/QC protocols, but no further correction was applied to the results. Sample detection limits for PAHs varied widely, from $0.02 \mathrm{ng} / \mathrm{L}$ for fluoranthene to $0.001 \mathrm{ng} / \mathrm{L}$ for anthracene. Precision ranged from $2.1 \%$ to $20.3 \%$, although most values were better than $10 \%$, and accuracy ranged from $2.7 \%$ to $13.4 \%$ and therefore was very good. The concentrations of the six most abundant PAHs in freshwater ecosystems were measured, namely, phenanthrene, anthracene, fluoranthene, pyrene, benzo[a]anthracene, and chrysene. The concentrations of all PAHs were summarized.

Some of the missing data on riverine water composition were derived from the literature [10-13]. The quarterly average data on the water discharge of the Selenga River and its tributaries were obtained for the years 2005, 2006, and 2009 from Khazheeva and Plyusnin [12] and used for CRR and CRC calculations. These data were chosen because the annual precipitation in the Selenga basin during these years was similar to that in 2015 [40]. Data on the trace metal composition of Baikal water were also derived from the literature $[17,18]$.

\section{Hydrochemical Characteristics of Lake Baikal and Its Tributaries}

The water in Lake Baikal and its tributaries is low-mineralized (the sum of ions does not exceed $100 \mathrm{mg} / \mathrm{L}$ ) and belongs to the bicarbonate class of the calcium group. The qualitative and quantitative similarities in chemical compositions between the lake and the majority of its tributaries are due to the cold humid climate causing low evaporation and low weathering rates. The most widespread rocks in the Baikal watershed are acidic igneous rocks, such as granites. In the upstream areas of the Selenga River watershed, carbonaceous rocks such as marbles are also widely distributed. Carbonaceous rocks cause slightly higher mineralization and alkalinity in the water of Selenga (especially in its upper reaches) relative to most of the studied tributaries. The highest values of water mineralization (up to $200 \mathrm{mg} / \mathrm{L}$ ) and alkalinity are observed in some small rivers of the western coast opposite of Olkhon island. Owing to the low population density in the Baikal watershed, the concentrations of organic and mineral contaminants in riverine and lake water are quite low. According to the Water Quality Guidelines for the Protection of Aquatic Life (CWQG) [41] developed by the Canadian Council of Ministers of the Environment (CCME), the surface waters of the Lake Baikal watershed can be considered unpolluted. 


\subsection{Chemical Composition of Riverine Waters}

The concentration of DOC in riverine waters varies from 7 to $18 \mathrm{mg} / \mathrm{L}$ during the spring and summer floods and from 1 to $3 \mathrm{mg} / \mathrm{L}$ during the period of winter base flow [12,42]. The highest DOC concentrations are observed in rivers of the western coast (such as Krestovka) that drain cold soils with high organic matter content (Table 1).

Table 1. Average chemical composition and water discharge of small tributaries of Lake Baikal. DOC: dissolved organic carbon; $\mathrm{N}_{\min }$ : mineral nitrogen; $\mathrm{PAH}$ : polycyclic aromatic hydrocarbon.

\begin{tabular}{|c|c|c|c|c|c|c|c|c|c|}
\hline Station & $\mathrm{Sr}$ & $\mathrm{Ti}$ & $\mathbf{N i}$ & $\mathbf{V}$ & Al & PAH & DOC & $\mathbf{N}_{\min }$ & $\mathbf{Q}$ \\
\hline & \multicolumn{6}{|c|}{$\mu \mathrm{g} / \mathrm{L}$} & \multicolumn{2}{|c|}{$\mathrm{mg} / \mathrm{L}$} & $\mathrm{m}^{3} / \mathrm{s}$ \\
\hline \multicolumn{10}{|c|}{ Krestovka, winter } \\
\hline 1 & 111 & 1.9 & 0.8 & 0.2 & 15.8 & 0.01 & 3 & 201 & 0.04 \\
\hline 2 & 89 & 1 & 0.5 & 0.7 & 13 & 0.01 & 3.9 & 268 & 0.06 \\
\hline \multicolumn{10}{|c|}{ Krestovka, spring } \\
\hline 1 & 50 & 2 & 0.7 & 0.3 & 60 & 0.02 & 10 & 25 & 1.2 \\
\hline 2 & 46 & 1.5 & 0.7 & 0.7 & 45 & 0.03 & 15 & 32 & 1.6 \\
\hline \multicolumn{10}{|c|}{ Krestovka, summer } \\
\hline 1 & 90 & 3.5 & 0.5 & 0.3 & 86 & 0.01 & 4 & 221 & 0.5 \\
\hline 2 & 83 & 2 & 0.7 & 0.8 & 71 & 0.02 & 6 & 292 & 0.6 \\
\hline \multicolumn{10}{|c|}{ Krestovka, autumn } \\
\hline 1 & 58 & 2.6 & 0.6 & 0.2 & 49 & 0.01 & 3 & 14 & 0.2 \\
\hline 2 & 53 & 2 & 0.7 & 0.6 & 35 & 0.01 & 4 & 17 & 0.3 \\
\hline \multicolumn{10}{|c|}{ Pereemnaya, summer } \\
\hline 1 & 50 & - & - & - & - & - & 3 & - & 2.2 \\
\hline 2 & 90 & - & - & - & - & - & 3 & - & 5.8 \\
\hline 3 & 20 & - & - & - & - & - & 2 & - & 2.3 \\
\hline 4 & 50 & - & - & - & - & - & 4 & - & 11 \\
\hline 5 & 30 & - & - & - & - & - & 2 & - & 2.6 \\
\hline 6 & 40 & - & - & - & - & - & 4 & - & 12 \\
\hline
\end{tabular}

The lowest DOC concentrations are observed in the Khamar-Daban ridge's small rivers, such as the Pereemnaya. The low DOC concentrations in the water of the Khamar-Daban rivers are due to extremely high precipitation (up to $1200 \mathrm{~mm} /$ year) and low OM content in soils because the positive annual soil temperatures favor high rates of OM decomposition [43].

The intermediate DOC concentrations are typical of big rivers (Selenga, Barguzin, Upper Angara, Snezhnaya) that drain large watersheds characterized by diverse environmental conditions. The DOC concentration in the Selenga River (Table 2) increases from the source to the mouth, reaching the maximum within the limits of the city Ulan-Ude. This is probably the result of anthropogenic contamination. Among the Selenga river tributaries, the highest spring DOC concentrations (Table 3) are observed in the Chikoy, Khilok, and Uda rivers, and the highest winter base flow concentrations are observed in the Dzhida and Uda rivers.

The PAH concentration in the water of Lake Baikal's tributaries varies from $24 \mathrm{ng} / \mathrm{L}$ during the spring and summer floods to $6 \mathrm{ng} / \mathrm{L}$ during the period of summer base flow [22,42]. The highest concentrations are observed in tributaries of the western coast, and the lowest concentrations are observed in major tributaries. Intermediate concentration values are typical for rivers of the Khamar-Daban ridge. Differences in PAH concentrations among the rivers are caused by several factors, such as water residence time, pollution level, and bioavailability of organic matter [22]. In the Selenga river, the PAH concentrations slightly increase with increasing distance from the source. The highest PAH concentrations among the Selenga tributaries are observed in the Dzhida and Temnik rivers. 
Table 2. Average chemical composition and water discharge of the Selenga River and Lake Baikal.

\begin{tabular}{|c|c|c|c|c|c|c|c|c|c|}
\hline Station & Sr & $\mathrm{Cu}$ & $\mathrm{Ni}$ & $\mathbf{V}$ & Al & РАH & DOC & $\mathbf{N}_{\min }$ & $\mathbf{Q}$ \\
\hline & \multicolumn{6}{|c|}{$\mu \mathrm{g} / \mathrm{L}$} & \multicolumn{2}{|c|}{$\mathrm{mg} / \mathrm{L}$} & $\mathrm{m}^{3} / \mathrm{s}$ \\
\hline \multicolumn{10}{|c|}{ Winter } \\
\hline 1 & 310 & 0.8 & 0.3 & 0.6 & 10 & 0.02 & 3.3 & 325 & 49 \\
\hline 2 & 320 & 1 & 0.3 & 0.5 & 9 & 0.02 & 4.1 & 277 & 59 \\
\hline 3 & 310 & 1.2 & 0.4 & 0.5 & 16 & 0.02 & 3.4 & 330 & 78 \\
\hline 4 & 340 & 1.2 & 0.5 & 0.5 & 10 & 0.03 & 3.7 & 522 & 92 \\
\hline 5 & 260 & 0.8 & 0.5 & 0.5 & 9 & 0.01 & 4.6 & 525 & 107 \\
\hline \multicolumn{10}{|c|}{ Spring } \\
\hline 1 & 150 & 1.8 & 0.9 & 0.9 & 8 & 0.02 & 4.3 & 23 & 297 \\
\hline 2 & 190 & 2 & 1 & 0.8 & 18 & 0.01 & 4.7 & 23 & 494 \\
\hline 3 & 120 & 1.5 & 0.9 & 0.9 & 50 & 0.004 & 5 & 29 & 633 \\
\hline 4 & 120 & 1.8 & 1 & 0.7 & 30 & 0.02 & 8.8 & 48 & 866 \\
\hline 5 & 100 & 1.6 & 1.2 & 1 & 50 & 0.03 & 6.3 & 46 & 902 \\
\hline \multicolumn{10}{|c|}{ Summer } \\
\hline 1 & 200 & 1.8 & 0.6 & 1.8 & 17 & 0.004 & 5 & 114 & 520 \\
\hline 2 & 210 & 1.8 & 0.7 & 2 & 18 & 0.01 & 4 & 115 & 1010 \\
\hline 3 & 160 & 1.7 & 0.6 & 1.4 & 10 & 0.01 & 3 & 150 & 1210 \\
\hline 4 & 150 & 1.5 & 0.6 & 1.4 & 17 & 0.01 & 7 & 286 & 1370 \\
\hline 5 & 140 & 1.4 & 0.6 & 1.3 & 20 & 0.004 & 5 & 298 & 1280 \\
\hline \multicolumn{10}{|c|}{ Autumn } \\
\hline 1 & 210 & 1.2 & 0.4 & 1.4 & 10 & 0.01 & 4.7 & 25 & 432 \\
\hline 2 & 230 & 1.3 & 0.4 & 1.4 & 7 & 0.004 & 3.8 & 23 & 840 \\
\hline 3 & 160 & 1.2 & 0.4 & 0.7 & 8 & 0.01 & 4.1 & 21 & 954 \\
\hline 4 & 160 & 1.2 & 0.4 & 0.6 & 10 & 0.01 & 4.3 & 35 & 1050 \\
\hline 5 & 160 & 1 & 0.5 & 0.6 & 9 & 0.004 & 4 & 33 & 1120 \\
\hline \multicolumn{10}{|c|}{ Baikal, summer } \\
\hline Angara & 119 & 0.2 & 0.1 & 0.4 & 0.3 & 0.001 & 1.4 & 0.05 & 1950 \\
\hline
\end{tabular}

Table 3. Average chemical composition and water discharge of the Selenga tributaries.

\begin{tabular}{|c|c|c|c|c|c|c|c|c|c|}
\hline River & Sr & $\mathrm{Cu}$ & $\mathrm{Ni}$ & V & Al & РAH & DOC & $\mathbf{N}_{\min }$ & $\mathbf{Q}$ \\
\hline & \multicolumn{6}{|c|}{$\mu \mathrm{g} / \mathrm{L}$} & \multicolumn{2}{|c|}{$\mathrm{mg} / \mathrm{L}$} & $\mathrm{m}^{3} / \mathrm{s}$ \\
\hline \multicolumn{10}{|c|}{ Winter } \\
\hline Chikoy & 320 & 1 & 0.3 & 0.5 & 9 & 0.01 & 2.7 & 482 & 14 \\
\hline Khilok & 315 & 1.1 & 0.4 & 0.5 & 10 & 0.01 & 2. 9 & 492 & 5 \\
\hline Uda & 330 & 1.1 & 0.5 & 0.5 & 10 & 0.01 & 4.8 & 364 & 13 \\
\hline Dzhida & 315 & 1 & 0.3 & 0.5 & 9 & 0.01 & 4.4 & 372 & 11 \\
\hline Temnik & 320 & 1.1 & 0.3 & 0.5 & 7 & 0.01 & 2.9 & 324 & 2 \\
\hline \multicolumn{10}{|c|}{ Spring } \\
\hline Chikoy & 190 & 2 & 1 & 0.8 & 18 & 0.01 & 6.4 & 28 & 157 \\
\hline Khilok & 140 & 1.8 & 0.9 & 0.9 & 50 & 0.004 & 8.1 & 31 & 83 \\
\hline Uda & 120 & 1.8 & 0.9 & 0.8 & 40 & 0.03 & 7.2 & 15 & 85 \\
\hline Dzhida & 175 & 1.8 & 0.9 & 0.9 & 10 & 0.01 & 5.5 & 17 & 36 \\
\hline Temnik & 175 & 1.7 & 0.9 & 0.8 & 12 & 0.01 & 4.8 & 15 & 31 \\
\hline \multicolumn{10}{|c|}{ Summer } \\
\hline Chikoy & 210 & 1.8 & 0.7 & 2 & 18 & 0.01 & 4 & 196 & 602 \\
\hline Khilok & 150 & 1.7 & 0.7 & 1.5 & 27 & 0.01 & 8 & 178 & 152 \\
\hline Uda & 150 & 1.7 & 0.6 & 1.4 & 17 & 0.004 & 3 & 162 & 69 \\
\hline Dzhida & 200 & 2 & 0.8 & 1.9 & 55 & 0.01 & 2 & 176 & 110 \\
\hline Temnik & 200 & 2 & 0.9 & 1.8 & 15 & 0.01 & 3 & 145 & 30 \\
\hline \multicolumn{10}{|c|}{ Autumn } \\
\hline Chikoy & 230 & 1.3 & 0.4 & 1.4 & 7 & 0.01 & 3.8 & 24 & 415 \\
\hline Khilok & 180 & 1.2 & 0.4 & 0.7 & 10 & 0.01 & 3.4 & 28 & 74 \\
\hline Uda & 175 & 1.2 & 0.4 & 0.6 & 9 & 0.004 & 5.8 & 12 & 72 \\
\hline Dzhida & 220 & 1.4 & 0.5 & 0.8 & 9 & 0.01 & 7.5 & 15 & 106 \\
\hline Temnik & 235 & 1.2 & 0.4 & 0.8 & 8 & 0.01 & 5.2 & 13 & 32 \\
\hline
\end{tabular}


The predominant trace metal species in riverine waters is strontium [18], and the Sr concentration found in this study reaches $350 \mu \mathrm{g} / \mathrm{L}$. It is the most abundant trace metal in carbonaceous rocks and calcareous soils, and it is often used as a tracer for calcium in geochemical, biological, and clinical research [43]. After Sr, the two most abundant metals in the water are $\mathrm{Al}$ and Fe. The concentrations of other trace metals in the water are 2-3 orders of magnitude lower.

The lowest concentrations are observed for $\mathrm{Sn}, \mathrm{Zn}, \mathrm{Cu}$, Ti, and Ni. The highest metal concentrations are observed in rivers of the western coast, and the lowest concentrations are detected in the rivers of the Khamar-Daban ridge. In the Selenga river, the concentrations of metals decrease from the source to the mouth. However, the highest values are observed downstream of the Ulan-Ude city [10], and this is definitely related to anthropogenic contamination. Among the Selenga tributaries, the highest $\mathrm{Sr}$, $\mathrm{Mn}, \mathrm{Fe}$, and $\mathrm{Zn}$ concentrations are observed in the Khilok and Uda rivers. These metals are likely of anthropogenic origin.

\subsection{Chemical Composition of Baikal Water}

The DOC concentration in the water of Lake Baikal (Table 2) is several times lower than that in riverine waters. This is probably because the lake has a water residence time of years to decades, whereas tributaries have residence times that range between one day and one week. The minimum concentrations (up to $0.7 \mathrm{mg} / \mathrm{L}$ ) in the surface layer of Lake Baikal water are observed in the northern basin during the winter, during which lake tributaries are fed by groundwater runoff. The maximum DOC concentrations (up to $1.5 \mathrm{mg} / \mathrm{L}$ ) are observed in the southern basin during spring, at which time the tributaries are fed by snowmelt runoff [44]. A slight increase in DOC concentration is also observed by the end of the ice-covered period as a result of the mass development of phytoplankton. The DOC concentration in the lake water also increases (up to $2-4 \mathrm{mg} / \mathrm{L}$ ) toward the mouths of inflow rivers $[45,46]$ and decreases with increasing depth. The sum concentration of six PAHs in Baikal water rarely exceeds $4 \mathrm{ng} / \mathrm{L}$, which is much less than that in tributary waters [21,42]. As in the case of DOC, this finding is due to the photo- and biodegradation processes that occur in the water in the lake.

The concentrations of the most abundant metals in the Earth's crust (e.g., $\mathrm{Al}, \mathrm{Fe}, \mathrm{Sr}, \mathrm{Ba}$, and $\mathrm{Mn})$ are similar between the lake and its tributaries [17,18]. The lake water concentrations of less abundant metals, such as $\mathrm{Ti}, \mathrm{V}, \mathrm{U}, \mathrm{Mo}, \mathrm{Cu}$, and $\mathrm{Ni}$, are much lower than that in riverine waters. The concentrations of most metals decrease with depth. As in the case of DOC, the metal enrichment of the Baikal water surface layer is conditioned by an inflow of riverine water that is rich in dissolved and particulate matter.

\section{Results and Discussion}

\subsection{Self-Purification of the Selenga River}

On the basis of correlations among the contaminant removal rates, all of the contaminants can be divided into one of four groups: (1) metals highly correlated with DOC; (2) non-metals highly correlated with DOC; (3) metals moderately and lowly correlated with DOC; (4) metals uncorrelated with DOC. The removal rate of PAHs is not correlated with the removal rate of any other solute.

\subsubsection{Elements Highly Correlated with DOC}

Metals correlated with DOC (V, U, Ni, Cu) occur with different abundances in the Earth's crust and have different chemical properties, which would suggest that their mechanisms of removal differ $[47,48]$. Nevertheless, the temporal and spatial patterns of the removal and release of $\mathrm{V}, \mathrm{U}, \mathrm{Ni}$, and $\mathrm{Cu}$ are similar. The removal of metals during the warm period of the year absolutely prevailed over their release during the cold period (Table 4). The lowest amplitude was typical for PAHs and some low-abundance metals such as $\mathrm{V}$ and $\mathrm{Ni}$. The highest summer rates of $\mathrm{V}$ and $\mathrm{Ni}$ removal were equal to $-607 \mathrm{mg} / \mathrm{s}$ and $-155 \mathrm{mg} / \mathrm{s}$, respectively, whereas lowest spring rates are equal to $296 \mathrm{mg} / \mathrm{s}$ and $220 \mathrm{mg} / \mathrm{s}$. 
The removal of $\mathrm{C}, \mathrm{V}, \mathrm{U}, \mathrm{Ni}$, and $\mathrm{Cu}$ observed at station 2 (Figure 2a-c) in summer is probably due to mountain-front recharge, i.e., the river's contribution to the groundwater recharge of adjacent basins along the mountain front [49]. This is evidenced by negative $\Delta \mathrm{Q}$ values. Although the water loss to the groundwater is the main mechanism of contaminant removal, it is not the only one. Metal $(\mathrm{Mn}, \mathrm{V}, \mathrm{Cu}$, $\mathrm{Ni}$ ) complexes of fulvic acids precipitate because the $\mathrm{pH}$, Eh, and mineralization all increase $[47,48]$ when tributaries merge into the main stream. Uranyl carbonate complexes are removed by binding to precipitating organic matter [47] in the main stream because $U$ concentration in tributary waters is higher and the DOC concentration is lower compared with Selenga water. The decrease in the removal of $\mathrm{Mn}, \mathrm{V}, \mathrm{Cu}$, and $\mathrm{Ni}$ observed at the subsequent stations is likely the result of decreased downstream mineralization and increased DOC concentration [9]. The presence of suspended sediments also facilitates the precipitation of OM and OM-bound metals [50,51]. Thus, it is also possible that the decrease in CRRs downstream from station 2 is due to a decrease in the concentration of suspended sediments $[52,53]$.

Table 4. Rates of contaminant removal from the Selenga River.

\begin{tabular}{|c|c|c|c|c|c|c|c|c|}
\hline Station & $\mathrm{Sr}$ & $\mathrm{Cu}$ & $\mathbf{N i}$ & $\mathbf{V}$ & Al & PAH & DOC & $\mathbf{N}_{\text {min. }}$ \\
\hline & \multicolumn{6}{|c|}{$\mathrm{mg} / \mathrm{s}$} & \multicolumn{2}{|c|}{$\mathrm{g} / \mathrm{s}$} \\
\hline \multicolumn{9}{|c|}{ Selenga, winter } \\
\hline 2 & -4895 & -7 & -6 & -15 & -198 & 0.2 & -11 & -11 \\
\hline 3 & 3725 & 29 & 8 & 6 & 667 & 0.04 & 4 & 7 \\
\hline 4 & 2810 & 3 & 8 & 2 & -458 & 1 & 12 & 18 \\
\hline 5 & -3460 & -25 & 8 & 9 & 43 & -2 & 155 & 8 \\
\hline \multicolumn{9}{|c|}{ Selenga, spring } \\
\hline 2 & 7755 & 22 & 9 & -54 & 2958 & -4 & -282 & -1 \\
\hline 3 & $-29,520$ & -188 & 1 & 129 & 18,608 & -0.3 & 163 & 4 \\
\hline 4 & 17,760 & 456 & 220 & -32 & -9070 & 16 & 3869 & -1 \\
\hline 5 & $-13,720$ & -116 & 171 & 296 & 19,120 & 10 & -1931 & -0.08 \\
\hline \multicolumn{9}{|c|}{ Selenga, summer } \\
\hline 2 & $-46,320$ & -482 & -155 & -378 & -7996 & -1 & -1278 & -85 \\
\hline 3 & $-41,300$ & -72 & -110 & -607 & $-10,184$ & 0.2 & -1626 & 38 \\
\hline 4 & 1550 & -55 & 170 & 123 & 10,017 & 7 & 5753 & -22 \\
\hline 5 & $-26,300$ & -263 & -109 & -250 & 2310 & -9 & -3190 & -10 \\
\hline \multicolumn{9}{|c|}{ Selenga, autumn } \\
\hline 2 & $-23,810$ & -153 & -68 & -118 & -2555 & -2 & -1402 & -3 \\
\hline 3 & $-53,880$ & -36 & -8 & -518 & 1012 & 2 & 516 & -1 \\
\hline 4 & 2760 & 29 & 50 & -81 & 2220 & 0.2 & 157 & -0.7 \\
\hline 5 & 11,200 & -140 & 119 & 42 & -420 & -1 & 26 & 0.2 \\
\hline
\end{tabular}

For example, the element removal rates at station 5 (Figure 2) are lower than those at station 2 despite the fact that element flow rates (and water discharge) are ten times higher at the former compared with the latter. The release of $\mathrm{Mn}, \mathrm{V}, \mathrm{Cu}$, and $\mathrm{Ni}$ into the water at station 4 is clearly linked to anthropogenic contamination. The correlation between metal and DOC concentrations at this station is due to organic and inorganic pollutants having common sources, such as industrial wastes and surface runoff from impervious surfaces $[54,55]$. It is known that the concentrations of most elements in Selenga water between the Chikoy River mouth and Uda River mouth substantially increase $[6,52,53]$. To some extent, the increasing concentrations are the result of the contamination of the Khilok River [56].

The removal of nonmetallic solutes during the warm period is equal to or a bit lower than their release during the cold period (Table 4). At stations 2 and 5, which are unaffected by pollution, the highest rates of $\mathrm{N}$ and $\mathrm{C}$ removal $(-85 \mathrm{~g} / \mathrm{s}$ and $-3190 \mathrm{~g} / \mathrm{s}$, respectively) were observed in summer and the lowest rates $(4 \mathrm{~g} / \mathrm{s}$ and $3869 \mathrm{~g} / \mathrm{s}$, respectively) were observed in the spring. The removal of DOC, $\mathrm{O}$, and $\mathrm{N}_{\min }$. in summer is to some extent due to biological uptake, whereas the release of these solutes in spring is due to contaminated melt water. The removal of DOC, $\mathrm{O}$, and $\mathrm{N}_{\min }$. at station 2 
(Figure 2d) is, to a degree, also affected by water losses across a mountain-to-valley transition [49]. The release of nonmetallic solutes in the other seasons is due to the low biological activity during these periods. The release of $\mathrm{N}_{\min }$. in summer observed at station 3 and the release of DOC observed at stations 3 and 4 are due to anthropogenic contamination. The absence of the release of nonmetallic solutes at station 5 in spring is probably due to the low contribution of surface flow to streamflow in the lower reach of the Selenga River.
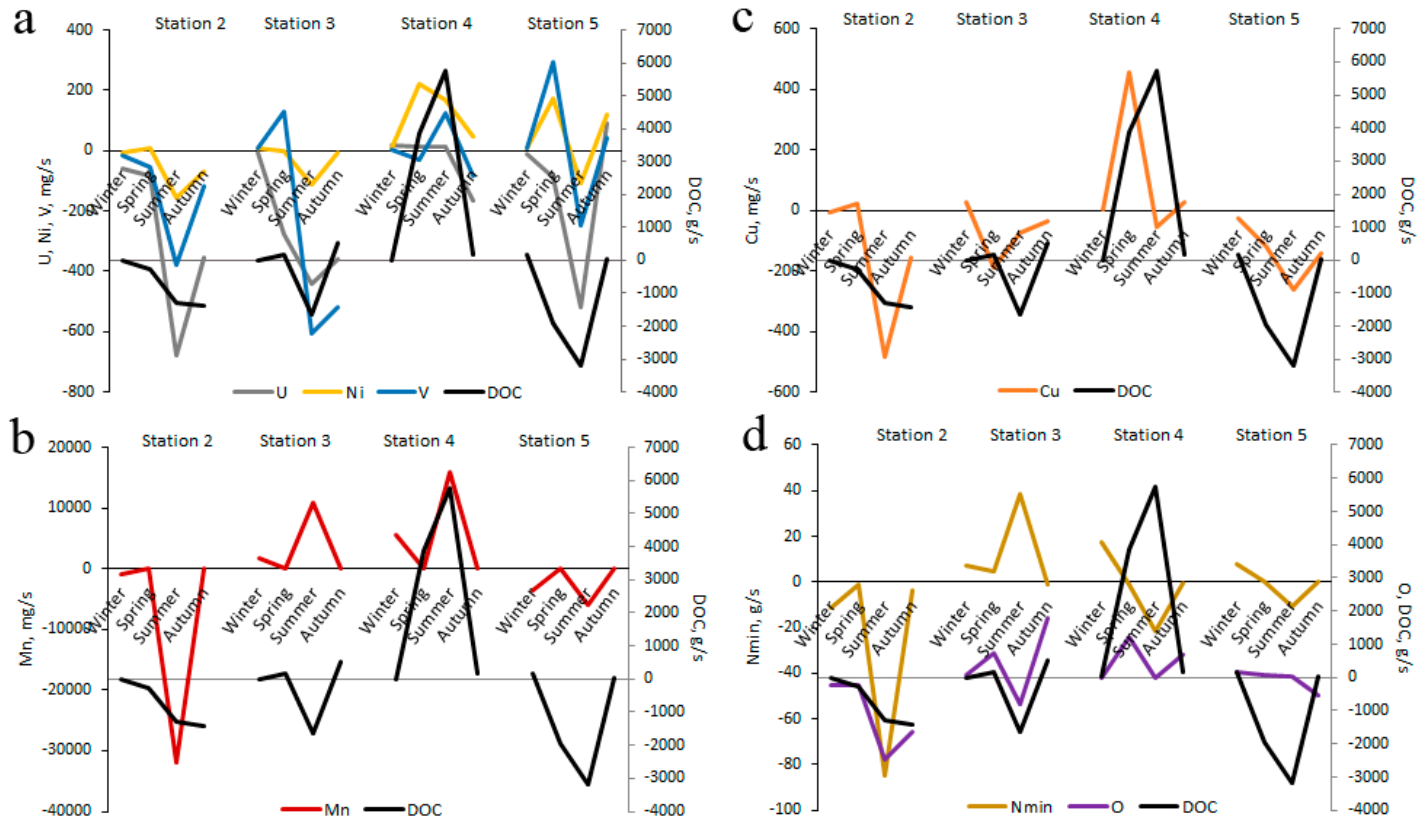

Figure 2. Spatial and temporal variation in removal rates of elements highly correlated with DOC. (a) $\mathrm{U}, \mathrm{Ni}, \mathrm{V},(\mathbf{b}) \mathrm{Mn},(\mathbf{c}) \mathrm{Cu},(\mathbf{d}) \mathrm{N}_{\min }, \mathrm{O}$.

\subsubsection{Elements Moderately Correlated and Uncorrelated with DOC}

The spatial and temporal removal/release patterns observed for metals that are moderately correlated with DOC, such as Sr, Ba, and Mo, are similar to those observed for elements highly correlated with DOC (Figure 3). The simultaneous decrease in Sr (Figure 3a), Ba (Figure 3b), and Mo (Figure 3c) removal rates in the downstream direction seems to result from decreasing concentrations of these metals in water. The decrease in metal concentration is in turn due to a decrease in the occurrence of carbonaceous rocks (limestone, marble, etc.) containing Sr and Ba [57] and ore-bearing porphyry containing Mo [58] in the downstream direction. The removal rates of Sr and Ba exceed the rates calculated for all considered elements. This is probably because most of the inorganic and organic salts of $\mathrm{Sr}$ and $\mathrm{Ba}$ are poorly soluble in water. Thus, high concentrations of $\mathrm{Sr}$ and $\mathrm{Ba}$ that migrate in the form of highly soluble bicarbonates lead to the high rates of Sr and Ba removal in the form of non-carbonaceous compounds. Moreover, there is also evidence for $\mathrm{Sr}, \mathrm{Ba}$, and Mo adsorption on carbonaceous particulate matter and the subsequent sedimentation of particulates [59,60]. Thus, the decrease in the concentration of particulate matter with the decrease in elevation also explains the decrease in $\mathrm{Sr}, \mathrm{Ba}$, and Mo removal rates. These findings contradict the idea that removal of $\mathrm{Sr}, \mathrm{Ba}$, and Mo from water occurs mostly through adsorption on $\mathrm{Al}, \mathrm{Fe}$, and Mn oxides [61,62]. However, there is no correlation between the removal of $\mathrm{Sr}, \mathrm{Ba}$, and $\mathrm{Mo}$ and the removal of $\mathrm{Al}, \mathrm{Fe}$, and $\mathrm{Mn}$. A correlation between metal and DOC removal rates is observed at stations 2 and 5 . The correlation at station 2 is conditioned by water losses, and that of station 5 is the result of the simultaneous sedimentation of carbonates and humates (or fulvates) of $\mathrm{Sr}, \mathrm{Ba}$, and Mo. The release of these metals at station 4 is probably due to contamination. However, the source of $\mathrm{Sr}, \mathrm{Ba}$, and Mo is different from that of DOC because there is no correlation between DOC and metal removal rates. 

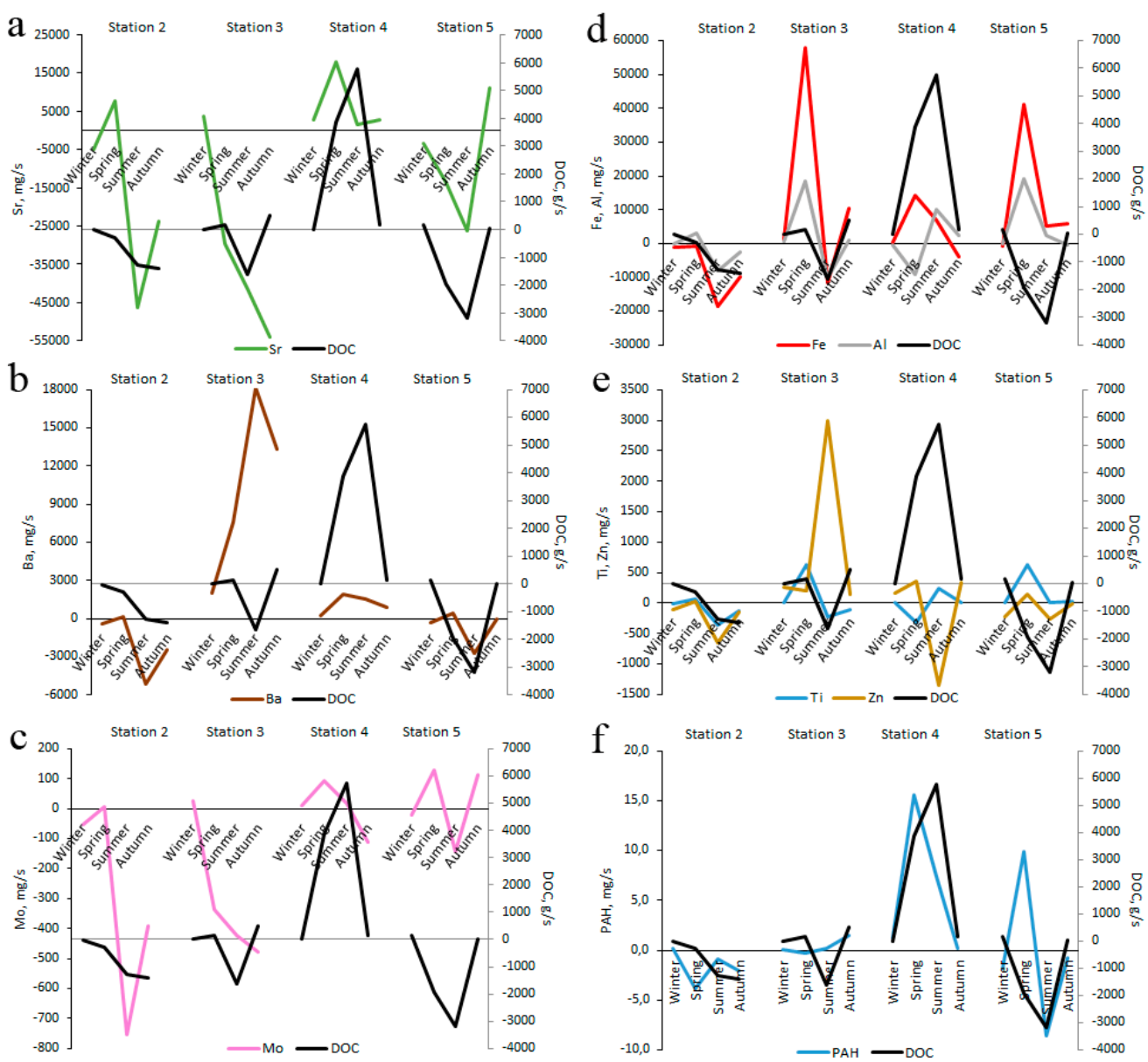

Figure 3. Spatial and temporal variation in the removal rates of elements that are moderately correlated and uncorrelated with DOC. (a) Sr, (b) Ba, (c) Mo, (d) Fe, Al, (e) Ti, Zn, (f) PAH.

The temporal patterns of removal/release of metals uncorrelated with $\mathrm{DOC}$ such as $\mathrm{Al}, \mathrm{Fe}$ (Figure 3d), Ti, and Zn (Figure 3e) are similar to those of the solutes correlated with DOC, although the rate of release of these metals is much higher than the rate of their removal at all stations except upper station 2. The low removal rates of $\mathrm{Al}, \mathrm{Fe}, \mathrm{Ti}$, and $\mathrm{Zn}$ are likely caused by the organic complexation and high solubility of these complexes $[63,64]$. Nevertheless, all of these metals are removed from water in the form of inorganic compounds. For example, in the alkaline water of Selenga and its tributaries, $\mathrm{Fe}$ may precipitate as iron oxide hydrate, $\mathrm{Fe}(\mathrm{OH})_{3}$. The release of $\mathrm{Al}, \mathrm{Fe}$, $\mathrm{Ti}$, and $\mathrm{Zn}$ into the water at stations 3 and 4 coincides with the release of DOC: this is indicative of their anthropogenic origin.

Any uncomplexed $\mathrm{Al}$ in water can be removed from solution through its reaction with dissolved $\mathrm{Si}$ [65]. Other metals such as $\mathrm{Fe}, \mathrm{Ti}$, and $\mathrm{Zn}$ can also be included in authigenic aluminosilicate precipitates. The displacement of $\mathrm{Al}$ from organic complexes also causes the removal of $\mathrm{Al}$ from solution. The displacement may be caused by an increase in major cation concentrations (when tributaries flow into Selenga) because these ions exchange with minor elements in organic complexes and on adsorption sites [65]. The release of $\mathrm{Zn}$ from electrochemically inert complexes may also be due to direct competition between $\mathrm{Zn}$ and some other metals for ligands in water [64]. Thus, the decrease in the removal of $\mathrm{Al}, \mathrm{Fe}$, and $\mathrm{Ti}$ that is observed downstream of station 2 (especially at station 5) is probably the result of a decrease in downstream mineralization and increase in DOC concentration.

Thus, the amplitude of annual CRR oscillations depends on contaminant abundance, whereas the spatial CRR variability depends on water chemistry and presence of pollution sources. The absence of any meaningful spatial and temporal patterns of the PAH removal rate (Figure $3 \mathrm{f}$ ) is probably because multiple point and nonpoint PAH emission sources and pathways drive the continuous release of 
PAHs into the river [21]. The removal of PAHs from water occurs through photo- and biodegradation, as well as through sorption on particulate matter and subsequent sedimentation [22].

\subsection{Self-Purification of the Selenga River Compared with Small Tributaries}

The calculated removal rates for the small tributaries of Lake Baikal (Table 5) are lower than those for the Selenga River (Table 4). This is undoubtedly linked to different water discharges in small and big rivers.

Table 5. Rates of contaminant removal from the small tributaries of Lake Baikal.

\begin{tabular}{|c|c|c|c|c|c|c|c|}
\hline Season/ & Sr & $\mathrm{Ni}$ & $\mathbf{V}$ & Al & РАН & DOC & $\mathbf{N}_{\min .}$ \\
\hline station & \multicolumn{5}{|c|}{$\mathrm{mg} / \mathrm{s}$} & \multicolumn{2}{|c|}{$\mathrm{g} / \mathrm{s}$} \\
\hline \multicolumn{8}{|c|}{ Krestovka } \\
\hline Winter & 0.9 & 0.00001 & 0.04 & 0.2 & 0.0004 & 0.1 & 8 \\
\hline Spring & 14 & 0.2 & 0.8 & -0.3 & 0.02 & 12 & 20 \\
\hline Summer & 9 & 0.2 & 0.3 & 4 & 0.01 & 2 & 76 \\
\hline Autumn & 2 & 0.06 & 0.1 & -1 & 0.002 & 0.4 & 1 \\
\hline \multicolumn{8}{|c|}{ Pereemnaya, summer } \\
\hline 2 & 415 & & & & & 11 & \\
\hline 4 & -47 & & & & & 20 & \\
\hline 6 & -138 & & & & & -0.7 & \\
\hline
\end{tabular}

However, the calculated values of contaminant removal capacity for major and small tributaries also show the differences between these two river categories. The lower CRC values in small tributaries are probably due to shorter water residence times that are insufficient for the completion of some self-purification reactions. This means that the river's self-purification is highly dependent on river channel characteristics, such as flow velocity, turbulence, riverbed relief, and grain size distribution of sediments $[9,31,66]$. For example, the high flow velocity in Pereemnaya and Krestovka rivers reduces the period of water contact with bottom sediments and hinders contaminant removal from water. The predominance of coarse sediments, as well as the low turbidity and salinity of Pereemnaya and Krestovka waters, is also the cause of low CRC values.

The prevalence of DOC release compared with the removal in Krestovka is due to high DOC concentrations in the tributaries of the western coast of Baikal [38]. The high DOC concentrations are the result of the cold climate-induced inhibition of soil organic matter decomposition. The prevalence of $\mathrm{N}_{\min }$. release relative to its removal in Krestovka is due to groundwater contamination by residential sewage [4].

To quantify the variability of output data the uncertainty analysis was performed. The combined uncertainty $(U)$ of CRR calculations was evaluated taking into account two uncertainty sources: uncertainty of contaminant concentration measurement and uncertainty of water discharge measurement. The uncertainty (standard deviation, $\sigma$ ) of concentration measurement is equal to $\pm 5 \%, \pm 10, \pm 10 \%$ for most of trace metals, PAHs, and $\mathrm{N}_{\min .}$, respectively. All the measurements were performed in triplicate the standard deviations were reduced by $\sqrt{3}$ times. Thus, the $\sigma$ values used for $\mathrm{U}$ calculations were equal to $\pm 2.9,5.8$, and 5.8 for trace metals, PAHs, and $\mathrm{N}_{\min .}$, respectively. The uncertainty of water discharge measurement ranged from $20 \%$ to $30 \%$ depending on river depth and width. Uncertainty of discharge measurement has an approximately rectangular distribution, thus the $Q$ value was also reduced by $\sqrt{3}$ times (11.6 and 17.3 for deep and shallow sites, respectively). The combined uncertainty was calculated according to the formula:

$$
U=k \sqrt{u_{\text {solute }}^{2}+u_{Q}^{2}}
$$


where $u_{\text {solute }}^{2}$-the squared uncertainty of solute measurement, $u_{Q}^{2}$-the squared uncertainty of water discharge measurement, and $k$-confidence multiplier ( 0.95 confidence interval).

The obtained $U$ values were in the range of $14-21 \%$ which makes the spatial and temporal changes in removal rates of most of contaminants distinguishable.

\subsection{Self-Purification of Lake Baikal Compared with Tributaries}

It is difficult to precisely evaluate contaminant removal from Lake Baikal using the mass balance approach because the number of tributaries is large, and the seasonal variability in contaminant concentrations, as well as that in water discharge, is high. Rough estimates based on the rates of contaminant export from the lake and tributaries (Table 6) suggest that the removal of all solutes (except Al) from the lake is much higher than that from rivers (Table 4). It means that CRR depends on the size of the water body. For example, the lowest and the highest CRRs observed for Baikal were equal to $-15 \mathrm{mg} / \mathrm{s}$ (PAHs) to $-7327 \mathrm{~g} / \mathrm{s}$ (DOC), whereas the highest PAH and DOC removal rates observed for the Selenga River (the major Baikal tributary) in summer were equal to $-9 \mathrm{mg} / \mathrm{s}$ and $-3190 \mathrm{~g} / \mathrm{s}$, correspondingly. The highest PAH and DOC removal rates observed for small tributaries were equal to $0.0004 \mathrm{mg} / \mathrm{s}$ and $-0.7 \mathrm{~g} / \mathrm{s}$, respectively. The higher removal rates obtained for most of the solutes are caused by the longer residence time of the water. The lower $\mathrm{Al}$ removal is probably due to its mobilization by autochthonous DOC.

To evaluate the contaminant removing capacity of Baikal, the change in water discharge $(\Delta \mathrm{Q})$ between the Baikal tributaries and the Angara River was calculated as the volume of water evaporated from the lake per second.

The multi-year average inflow-outflow difference, which is equal to $-3 \%\left(-59 \mathrm{~m}^{3} / \mathrm{s}\right)$ according to Afanasiev [63], was also used as the $\Delta \mathrm{Q}$ value in the CRC calculations (Table 7). The summer and autumn CRC values calculated for tributaries are higher than the corresponding CRC values calculated for Baikal. For example, the DOC removing capacity value of Baikal was equal to $-26 \mathrm{~g} / \mathrm{m}^{3}$ whereas that of Selenga in summer was equal to $-118 \mathrm{~g} / \mathrm{m}^{3}$. This is likely caused by the higher mineralization and turbidity of riverine waters (including water in the upper Selenga reaches) with respect to Baikal water. The only solute that is removed from Baikal water in summer more effectively than from riverine water is $\mathrm{N}_{\mathrm{min}}$. Mineral nitrogen is removed from lake water through uptake by micro- and macrophytes. However, annual average CRC values in Lake Baikal are higher than the calculated CRC values in winter and spring in the Selenga river and small tributaries for corresponding solutes (Table 8). For example, the DOC removing capacity value of Baikal was equal to $-26 \mathrm{~g} / \mathrm{m}^{3}$ whereas DOC CRCs of all tributaries during the cold seasons varied from $505 \mathrm{mg} / \mathrm{m}^{3}$ to $-10 \mathrm{~g} / \mathrm{m}^{3}$. This is probably the result of the much longer residence time of Baikal water with respect to riverine waters. The CRC values of Baikal that were calculated using $\Delta Q$ from Afanasiev [67] are several times higher than those calculated using evaporation-induced water loss.

Table 6. Rates of contaminant export from Lake Baikal and tributaries; rates of contaminant removal from the lake; water discharge from the lake and tributaries.

\begin{tabular}{|c|c|c|c|c|c|c|c|c|c|}
\hline & Sr & $\mathrm{Cu}$ & $\mathbf{V}$ & $\mathrm{Ni}$ & Al & PAH & DOC & $\mathbf{N}_{\min .}$ & Q \\
\hline & \multicolumn{6}{|c|}{$\mathrm{mg} / \mathrm{s}$} & \multicolumn{2}{|c|}{$\mathrm{g} / \mathrm{s}$} & $\mathrm{m}^{3} / \mathrm{s}$ \\
\hline & \multicolumn{9}{|c|}{ Rates of contaminant export from tributaries } \\
\hline Southern tributaries & 77,795 & 175 & 1944 & 45 & 345 & 11 & 3201 & 198 & 565 \\
\hline Upper Angara + Tyya & 12,618 & 216 & 72 & 75 & 150 & 1 & 1116 & 48 & 300 \\
\hline Barguzin & 17,217 & 140 & 144 & 54 & 48 & 1 & 587 & 38 & 150 \\
\hline \multirow[t]{2}{*}{ Selenga } & 157,295 & 907 & 1748 & 458 & 271 & 4 & 5096 & 206 & 935 \\
\hline & \multicolumn{9}{|c|}{ Rates of contaminant export from Baikal } \\
\hline \multirow[t]{2}{*}{ Angara } & 231,134 & 410 & 800 & 234 & 566 & 2 & 2672 & 98 & 1950 \\
\hline & \multicolumn{9}{|c|}{ Rates of contaminant removal from Lake Baikal } \\
\hline Angara & $-33,791$ & -102 & -3109 & -398 & -248 & -15 & -7327 & -391 & 1950 \\
\hline
\end{tabular}


Table 7. Values of contaminant removal capacity of the Selenga River and Lake Baikal, and $\Delta \mathrm{Q}$ values used for calculations.

\begin{tabular}{|c|c|c|c|c|c|c|c|c|c|}
\hline Station & Sr & $\mathrm{Cu}$ & $\mathbf{N i}$ & V & Al & РАН & DOC & $\mathbf{N}_{\min }$ & $\Delta \mathrm{Q}$ \\
\hline & \multicolumn{6}{|c|}{$\mathrm{mg} / \mathrm{m}^{3}$} & \multicolumn{2}{|c|}{$\mathrm{g} / \mathrm{m}^{3}$} & $\mathrm{~m}^{3} / \mathrm{s}$ \\
\hline \multicolumn{10}{|c|}{ Selenga, winter } \\
\hline 2 & -288 & -0.4 & -0.3 & -0.9 & -12 & 0.01 & -0.7 & -0.7 & -17 \\
\hline 3 & 266 & 2 & 0.6 & 0.5 & 48 & 0.003 & 0.3 & 0.5 & 14 \\
\hline 4 & 2810 & 3 & 8 & 2 & -458 & 1 & 12 & 18 & 1 \\
\hline 5 & -231 & -2 & 0.6 & 0.6 & 3 & -0.1 & 10 & 0.5 & 15 \\
\hline \multicolumn{10}{|c|}{ Selenga, spring } \\
\hline 2 & 287 & 0.8 & 0.3 & -2 & 110 & -0.1 & -10 & -0.04 & -27 \\
\hline 3 & -527 & -3 & 0.02 & 2 & 332 & -0.005 & 3 & 0.08 & 56 \\
\hline 4 & 120 & 3 & 1 & -0.2 & -61 & 0.1 & 26 & -0.009 & 148 \\
\hline 5 & -381 & -3 & 5 & 8 & 531 & 0.3 & -54 & -0.002 & 36 \\
\hline \multicolumn{10}{|c|}{ Selenga, summer } \\
\hline 2 & -184 & -2 & -0.6 & -1 & -32 & -0.003 & -5 & -0.3 & -252 \\
\hline 3 & -860 & -2 & -2.3 & -13 & -212 & 0.005 & -34 & 0.8 & 48 \\
\hline 4 & 17 & --0.6 & 2 & 1 & 110 & 0.08 & 63 & -0.2 & 91 \\
\hline 5 & -292 & -3 & -1 & -3 & 26 & -0.1 & -35 & -0.1 & -90 \\
\hline \multicolumn{10}{|c|}{ Selenga, autumn } \\
\hline 2 & -164 & -1 & -0.5 & -0.8 & -18 & -0.01 & -10 & -0.002 & -145 \\
\hline 3 & -1347 & -0.9 & -0.2 & -13 & 25 & 0.04 & 13 & -0.003 & 40 \\
\hline 4 & 115 & 1 & 2 & -3 & 93 & 0.008 & 7 & -0.003 & 24 \\
\hline 5 & 160 & -2 & 2 & 0.6 & -6 & -0.01 & 0.4 & 3 & 70 \\
\hline \multicolumn{10}{|c|}{ Baikal } \\
\hline Angara & -119 & -4 & -11 & -1 & -1 & -0.1 & -26 & -1 & -285 \\
\hline Angara & -573 & -17 & -7 & -53 & -4 & -0.3 & -124 & -7 & -59 \\
\hline
\end{tabular}

Table 8. Values of contaminant removal capacity of small tributaries of Lake Baikal, and $\Delta \mathrm{Q}$ values used for calculations.

\begin{tabular}{|c|c|c|c|c|c|c|c|c|}
\hline Season/ & Sr & $\mathrm{Ni}$ & $\mathbf{V}$ & Al & РАН & DOC & $\mathrm{N}_{\min }$ & $\Delta Q$ \\
\hline station & \multicolumn{5}{|c|}{$\mathrm{mg} / \mathrm{m}^{3}$} & \multicolumn{2}{|c|}{$\mathrm{g} / \mathrm{m}^{3}$} & $\mathrm{~m}^{3} / \mathrm{s}$ \\
\hline \multicolumn{9}{|c|}{ Krestovka } \\
\hline Winter & 45 & 0.001 & 2 & 8 & 0.02 & 6 & 401 & 0.02 \\
\hline Spring & 34 & 0.4 & 2 & -0.8 & 0.06 & 30 & 50 & 0.4 \\
\hline Summer & 62 & 1 & 2 & 25 & 0.04 & 12 & 505 & 0.2 \\
\hline Autumn & 33 & 1 & 2 & -20 & 0.04 & 8 & 29 & 0.05 \\
\hline \multicolumn{9}{|c|}{ Pereemnaya, summer } \\
\hline 2 & 115 & & & & & 3 & & 4 \\
\hline 4 & -20 & & & & & 9 & & 2 \\
\hline 6 & -93 & & & & & -0.5 & & -2 \\
\hline
\end{tabular}

\section{Conclusions}

In this study the removal of trace metals (TM), dissolved organic carbon (DOC), mineral nitrogen $\left(\mathrm{N}_{\mathrm{min}}\right)$, and polycyclic aromatic hydrocarbons (PAHs) from the water of Lake Baikal and its tributaries was evaluated. The main conclusions were drawn as follows:

(1) The variety of environmental conditions in large watersheds results in a variety of contaminants in surface waters and a variety of processes that are responsible for contaminant removal. One such process is seepage loss from the river to the groundwater. The chemical processes of contaminant 
removal from the freshwater bodies of the Baikal watershed are probably the co-precipitation of organic and inorganic solutes with particulate matter, insoluble hydroxides, and authigenic aluminosilicates.

(2) The effectiveness of these processes increases with increasing salinity and turbidity and decreases with increasing concentrations of organic matter. Nevertheless, the realization of self-purification processes primarily depends on a few watershed morphometric characteristics that control the most important freshwater ecosystem parameters, such as biological activity, water residence time, and the area of mineral surfaces exposed to water.

(3) The highest rates of contaminant removal are observed in Lake Baikal, which is characterized by the highest water residence time. The highest rates of contaminant removal from tributary waters are observed in summer when the maximum length and width of river channels coincide with the maximum salinity and density of microbial and algal populations. The Selenga river's upper reaches are characterized by higher salinity and turbidity with respect to the lower reaches, as well as higher contaminant removal rates. The lowest rates are found for the small Krestovka river, which is characterized by high organic matter concentrations.

Author Contributions: M.Y.S. designed the research, M.Y.S. and Y.M.S. analyzed the data, A.V.S. drew the sampling map, and L.A.B. performed the chemical analyses.

Funding: This work was supported by the Russian Academy of Sciences, Government contracts No. 0345-2019-0008 (AAAA-A16-116122110065-4) and No. 0347-2019-0003 (AAAA-A17-117041910172-4) (fieldwork and chemical analyses), the Russian Fund of Basic Research, grants 17-45-388054 (data analysis) and 17-29-05068 (mapping), and by the Government of Irkutsk Region.

Conflicts of Interest: The authors declare no conflict of interest.

\section{References}

1. Kozhowa, O.M.; Silow, E. The current problems of Lake Baikal ecosystem conservation. Lakes Reserv. Res. Manag. 1998, 3, 19-33. [CrossRef]

2. Butorina, L.G. Lake Baikal and Other Great Lakes of Asia. In The Lakes Handbook: Restoration and Rehabilitation; O'Sullivan, P.E., Reynolds, C.S., Eds.; Blackwell Publishing: Oxford, UK, 2005; pp. 179-199.

3. Timoshkin, O.A.; Moore, M.V.; Kulikova, N.N.; Tomberg, I.V.; Malnik, V.V.; Shimaraev, M.N.; Troitskaya, E.S.; Shirokaya, A.A.; Sinyukovich, V.N.; Zaitseva, E.P.; et al. Groundwater contamination by sewage causes benthic algal outbreaks in the littoral zone of Lake Baikal (East Siberia). J. Great Lakes Res. 2018, 44, 230-244. [CrossRef]

4. Khodzher, T.V.; Domysheva, V.M.; Sorokovikova, L.M.; Sakirko, M.V.; Tomberg, I.V. Current chemical composition of Lake Baikal water. Inland Waters 2017, 7, 250-258. [CrossRef]

5. Potemkina, T.G.; Potemkin, V.L.; Kotsar, O.V.; Fedotov, A.P. Climate factors as a possible trigger of modern ecological changes in shallow zone of Lake Baikal (Russia). Int. J. Environ. Stud. 2018, 75, 86-98. [CrossRef]

6. Chalov, S.; Jarsjö, J.; Kasimov, N.; Romanchenko, A.; Pietron, J.; Thorslund, J.; Belozerova, E. Spatio-temporal variation of sediment transport in the Selenga River Basin, Mongolia and Russia. Environ. Earth Sci. 2015, 73, 663-680. [CrossRef]

7. Potemkina, T.G.; Fialkov, V.A. The balance of suspended load in Selenga Delta and its distribution in Lake Baikal. Water Resour. 1993, 20, 689-692.

8. Chalov, S.; Thorslund, J.; Kasimov, N.; Aybullatov, D.; Ilyicheva, E.; Karthe, D.; Kositsky, A.; Lychagin, M.; Nittrouer, J.; Pavlov, M.; et al. The Selenga River delta: A geochemical barrier protecting Lake Baikal waters. Reg. Environ. Chang. 2017, 17, 2039-2053. [CrossRef]

9. Gagarinova, O.V. Resistance of Natural Waters within the Lake Baikal Watershed to Anthropogenic Impacts. Geogr. Nat. Resour. 2015, 36, 40-47. [CrossRef]

10. Chebykin, E.P.; Sorokovikova, L.M.; Tomberg, I.V.; Rasskazov, S.V.; Khodzher, T.V.; Grachev, M.A. Current state of the Selenga River waters in the Russian territory concerning major components and trace elements. Chem. Sustain. Dev. 2012, 20, 561-580.

11. Khazheeva, Z.I.; Plyusnin, A.M. Discharge of biogenic substances with river runoff in Selenga basin. Water Resour. 2012, 39, 420-431. [CrossRef] 
12. Khazheeva, Z.I.; Plyusnin, A.M. The regime of dissolved gases and organic matter in Selenga basin rivers. Water Resour. 2013, 40, 61-73. [CrossRef]

13. Sorokovikova, L.M.; Sinyukovich, V.N.; Tomberg, I.V.; Marinaite, I.I.; Khodzher, T.V. Assessing the water quality in the tributary streams of Lake Baikal from chemical parameters. Geogr. Nat. Resour. 2015, 36, 31-39.

14. Sorokovikova, L.M.; Popovskaya, G.I.; Tomberg, I.V.; Bashenkhaeva, N.V. Space and time variations in concentrations of biogenic and organic matter and phytoplankton in the water of the Selenga River and its delta branches. Water Resour. 2009, 36, 443-452. [CrossRef]

15. Sorokovikova, L.M.; Tulokhonov, A.K.; Sinyukovich, V.N.; Popovskaya, G.I.; Nikulina, I.G.; Tomberg, I.V.; Bashenkhaeva, N.V.; Maksimenko, S.Y.; Pogodaeva, T.V.; Il'icheva, E.A.; et al. Water Quality in the Selenga Delta. Geogr. Nat. Resour. 2005, 1, 73-80. (In Russian)

16. Khazheeva, Z.I.; Urbazaeva, S.D.; Tulokhonov, A.K.; Plyusnin, A.M.; Sorokovikova, L.M.; Sinyukovich, V.N. Heavy Metals in the Water and Bottom Sediments of the Selenga River Delta. Geochem. Int. 2005, 43, 93-99. (In Russian) [CrossRef]

17. Falkner, K.K.; Measures, C.I.; Herbelin, S.E.; Edmond, J.M.; Weiss, R.F. The major and minor element geochemistry of Lake Baikal. Limnol. Oceanogr. 1991, 36, 413-423. [CrossRef]

18. Falkner, K.K.; Church, M.; Measures, C.I.; LeBaron, G.; Thouron, D.; Jeandel, C.; Stordal, M.C.; Gill, G.A.; Mortlock, R.; Froelich, P.; et al. Minor and trace element chemistry of Lake Baikal, its tributaries, and surrounding hot springs. Limnol. Oceanogr. 1997, 42, 329-345. [CrossRef]

19. Tomberg, I.V.; Sorokovikova, L.M.; Popovskaya, G.I.; Bashenkhaeva, N.V.; Sinyukovich, V.N.; Ivanov, V.G. Concentration dynamics of biogenic elements and phytoplankton at Selenga, R. Mouth and in Selenga shallows (Lake Baikal). Water Resour. 2014, 41, 687-695. [CrossRef]

20. Chebykin, E.P.; Goldberg, E.L.; Kulikova, N.S. Elemental composition of suspended particles from the surface waters of Lake Baikal in the zone affected by the Selenga River. Russ. Geol. Geophys. 2010, 51, 1126-1132. [CrossRef]

21. Semenov, M.Y.; Marinaite, I.I.; Golobokova, L.P.; Khuriganova, O.I.; Khodzher, T.V.; Semenov, Y.M. Source apportionment of polycyclic aromatic hydrocarbons in Lake Baikal water and adjacent air layer. Chem. Ecol. 2017, 33, 977-990. [CrossRef]

22. Semenov, M.Y.; Marinaite, I.I.; Zhuchenko, N.A.; Silaev, A.V.; Vershinin, K.E.; Semenov, Y.M. Revealing the factors affecting occurrence and distribution of polycyclic aromatic hydrocarbons in water and sediments of Lake Baikal and its tributaries. Chem. Ecol. 2018, 34, 901-916. [CrossRef]

23. Suslova, M.Y.; Pestunova, O.S.; Sukhanova, E.V.; Shtykova, Y.R.; Kostornova, T.Y.; Khanaev, I.V.; Sakirko, M.V.; Parfenova, V.V. Role of Cultured Microorganisms from Biofilms Formed on Rocky Substrates, M.V. in the Lake Baikal Self-Purification System. Microbiology 2018, 87, 788-795. [CrossRef]

24. Mizandrontsev, I.B.; Mizandrontseva, K.N. Influence of river runoff on the gas exchange of northern Baikal with atmosphere. Russ. Meteorol. Hydrol. 1999, 11, 58-65. (In Russian)

25. Domysheva, V.M.; Sakirko, M.V.; Pestunov, D.A.; Panchenko, M.V. Experimental assessment of the carbon dioxide flow in the atmosphere-water system of the littoral and pelagic zones of Lake Baikal during hydrological summer. Dokl. Earth Sci. 2010, 431, 541-545. [CrossRef]

26. Edel'shtein, K.K.; Puklakov, V.V.; Datsenko, Y.S.; Erina, O.N.; Sokolov, D.I. The Rate of Oxygen Release from Freshwater Bodies. Water Resour. 2018, 45, 399-408. [CrossRef]

27. Gonzalez, S.O.; Almeida, C.A.; Calderon, M.; Mallea, M.A.; González, P. Assessment of the water self-purification capacity on a river affected by organic pollution: Application of chemometrics in spatial and temporal variations. Environ. Sci. Pollut. Res. 2014, 21, 10583-10593. [CrossRef]

28. Karbassi, A.; Marefat, A. The impact of increased oxygen conditions on heavy metal flocculation in the Sefidrud estuary. Mar. Pollut. Bull. 2017, 121, 168-175. [CrossRef]

29. Finlay, J.C.; Small, G.E.; Sterner, R.W. Human influences on nitrogen removal in lakes. Science 2013, 342, 247-250. [CrossRef]

30. Tong, Y.; Li, J.; Qi, M.; Zhang, X.; Wang, M.; Liu, X.; Zhang, W.; Wang, X.; Lu, Y.; Lin, Y. Impacts of water residence time on nitrogen budget of lakes and reservoirs. Sci. Total Environ. 2019, 646, 75-83. [CrossRef]

31. Sauvage, S.; Sánchez-Pérez, J.-M.; Vervier, P.; Naiman, R.-J.; Alexandre, H.; Bernard-Jannin, L.; Boulêtreau, S.; Delmotte, S.; Julien, F.; Peyrard, D.; et al. Modelling the role of riverbed compartments in the regulation of water quality as an ecological service. Ecol. Eng. 2018, 118, 19-30. [CrossRef] 
32. Martin, P.; Cherukuru, N.; Tan, A.S.Y.; Sanwlani, N.; Mujahid, A.; Müller, M. Distribution and cycling of terrigenous dissolved organic carbon in peatland-draining rivers and coastal waters of Sarawak, Borneo. Biogeosciences 2018, 15, 6847-6865. [CrossRef]

33. Catalán, N.; Casas-Ruiz, J.P.; Arce, M.I.; Abril, M.; Bravo, A.G.; del Campo, R.; Estévez, E.; Freixa, A.; Giménez-Grau, P.; González-Ferreras, A.M.; et al. Behind the scenes: Mechanisms regulating climatic patterns of dissolved organic carbon uptake in headwater streams. Glob. Biogeochem. Cycles 2018, 32, 1528-1541. [CrossRef]

34. Han, T.; Zhang, H.; Hu, W.; Deng, J.; Li, Q.; Zhu, G. Research on self-purification capacity of Lake Taihu. Environ. Sci. Pollut. Res. 2015, 22, 8201-8215. [CrossRef]

35. Xiong, G.; Wang, G.; Wang, D.; Yang, W.; Chen, Y.; Chen, Z. Spatio-Temporal Distribution of Total Nitrogen and Phosphorus in Dianshan Lake, China: The External Loading and Self-Purification Capability. Sustainability 2017, 9, 500. [CrossRef]

36. Duan, W.; He, B.; Chen, Y.; Zou, S.; Wang, Y.; Nover, D.; Yang, G. Identification of long-term trends and seasonality in high-frequency water quality data from the Yangtze River basin, China. PLoS ONE 2018, 13, e0188889. [CrossRef]

37. Duan, W.; Takara, K.; He, B.; Luo, P.; Nover, D.; Yamashiki, Y. Spatial and temporal trends in estimates of nutrient and suspended sediment loads in the Ishikari River, Japan, 1985 to 2010. Sci. Total Environ. 2013, 461, 499-508. [CrossRef]

38. Duan, W.; He, B.; Nover, D.; Yang, G.; Chen, W.; Meng, H.; Zou, S.; Liu, C. Water Quality Assessment and Pollution Source Identification of the Eastern Poyang Lake Basin Using Multivariate Statistical Methods. Sustainability 2016, 8, 133. [CrossRef]

39. Duan, W.; He, B.; Takara, K.; Luo, P.; Nover, D.; Sahu, N.; Yamashiki, Y. Spatiotemporal evaluation of water quality incidents in Japan between 1996 and 2007. Chemosphere 2013, 93, 946-953. [CrossRef]

40. Dorjsuren, B.; Yan, D.; Wang, H.; Chonokhuu, S.; Enkhbold, A.; Yiran, X.; Girma, A.; Gedefaw, M.; Abiyu, A. Observed Trends of Climate and River Discharge in Mongolia's Selenga Sub-Basin of the Lake Baikal Basin. Water 2018, 10, 1436. [CrossRef]

41. CCME (Canadian Council of Ministers of the Environment). Canadian Water Quality Guidelines for the Protection of Aquatic Life: Summary Tables. Updated Canadian Environmental Quality Guidelines (2014). Available online: http://ceqg-rcqe.ccme.ca/en/index.html\#void (accessed on 9 May 2019).

42. Semenov, M.Y.; Semenov, Y.M.; Silaev, A.V.; Marinaite, I.I.; Snytko, V.A. Indicators of Pollution of Surface Waters of Lake Baikal Watershed by Polycyclic Aromatic Hydrocarbons. Dokl. Earth Sci. 2018, 483, $212-215$. [CrossRef]

43. Semenov, M.Y.; Sandimirova, G.P.; Korovyakova, I.V.; Troitskaya, E.S.; Khramtsova, T.I.; Donskaya, T.V. Comparative assessment of soil weathering rates in the landscapes of the northern slope of the Khamar-Daban ridge. Geol. Geofiz. 2005, 46, 50-59.

44. Votintsev, K.K. Gidrokhimiya Ozera Baikal [Hydrochemistry of Lake Baikal]; Russian Academy of Sciences: Moscow, Russia, 1961; 311p.

45. Yoshioka, T.; Mostofa, K.M.G.; Konohira, E.; Tanoue, E.; Hayakawa, K.; Takahashi, M.; Ueda, S.; Katsuyama, M.; Khodzher, T.; Bashenkhaeva, N.; et al. Distribution and characteristics of molecular size fractions of freshwater dissolved organic matter in watershed environments: Its implication to degradation. Limnology 2007, 8, 29-44. [CrossRef]

46. Sugiyama, Y.; Hatcher, P.G.; Sleighter, R.L.; Suzuki, T.; Wada, C.; Kumagai, T.; Mitamura, O.; Katano, T.; Nakano, S.; Tanaka, Y.; et al. Developing an understanding of dissolved organic matter dynamics in the giant Lake Baikal by ultrahigh resolution mass spectrometry. Limnology 2014, 15, 127-139. [CrossRef]

47. Cumberland, S.A.; Douglas, G.; Grice, K.; Moreau, J.W. Uranium Mobility in Organic Matter-Rich Sediments: A Review of Geological and Geochemical Processes. Earth-Sci. Rev. 2016, 159, 160-185. [CrossRef]

48. Schnitzer, M.; Kerndorff, H. Reaction of fulvic acid metal ions. Water Air Soil Pollut. 1981, 15, 97-108. [CrossRef]

49. Covino, T.P.; McGlynn, B.L. Stream gains and losses across a mountain-to-valley transition: Impacts on watershed hydrology and stream water chemistry. Water Resour. Res. 2007, 43, W10431. [CrossRef]

50. Hunter, K.A.; Liss, P.S. Organic matter and the surface charge of suspended particles in estuarine waters. Limnol. Oceanogr. 1982, 27, 322-335. [CrossRef] 
51. Davis, J.A. Adsorption of natural dissolved organic matter at the oxide/water interface. Geochim. Cosmochim. Acta 1982, 46, 2381-2393. [CrossRef]

52. Kasimov, N.S.; Lychagin, M.Y.; Chalov, S.R.; Shinkareva, G.L.; Pashkina, M.P.; Romanchenko, A.O.; Promakhova, E.V. Catchment based analysis of matter flows in the Selenga-Baikal system. Mosc. Univ. Bull. Ser. 5 Geogr. 2016, 3, 67-81. (In Russian)

53. Lychagin, M.; Chalov, S.; Kasimov, N.; Shinkareva, G.; Jarsjo, J.; Thorslund, J. Surface water pathways and fluxes of metals under changing environmental conditions and human interventions in the Selenga River system. Environ. Earth Sci. 2017, 76, 1. [CrossRef]

54. Jartun, M.; Ottesen, R.T.; Steinnes, E.; Volden, T. Runoff of particle bound pollutants from urban impervious surfaces studied by analysis of sediments from stormwater traps. Sci. Total Environ. 2008, 396, 147-163. [CrossRef]

55. Xiao, Y.; Zhang, T.; Wang, L.; Liang, D.; Xu, X. Analytical and experimental study on dissolved pollutant wash-off over impervious surfaces. Hydrol. Process. 2017, 31, 4520-4529. [CrossRef]

56. Zhuldybina, T. Pollution of rivers in Trans-Baikal territory. Vestn. Chita State Univ. 2009, 1, 40-45. (In Russian)

57. Fedotov, A.P.; Chebykin, E.P.; Semenov, M.Y.; Vorobyova, S.S.; Osipov, E.Y.; Golobokova, L.P.; Pogodaeva, T.V.; Zheleznyakova, T.O.; Grachev, M.A.; Tomurhuu, D.; et al. Changes in the volume and salinity of Lake Khubsugul (Mongolia) in response to global climate changes in the upper Pleistocene and the Holocene. Palaeogeogr. Palaeoclimatol. Palaeoecol. 2004, 209, 245-257. [CrossRef]

58. Solongo, T.; Fukushi, K.; Altansukh, O.; Takahashi, Y.; Akehi, A.; Baasansuren, G.; Ariuntungalag, Y.; Enkhjin, O.; Davaajargal, B.; Davaadorj, D.; et al. Distribution and Chemical Speciation of Molybdenum in River and Pond Sediments Affected by Mining Activity in Erdenet City, Mongolia. Minerals 2018, 8, 288. [CrossRef]

59. Chertko, N.K.; Chertko, E.N. Geochemistry and Ecology of Chemical Elements [Geokhiniya b Ecologiya Khimicheskihk Elementov]; Belarus State University: Minsk, Russia, 2008; 140p. (In Russian)

60. Goleva, G.A. Hydrogeochemistry of Ore Elements [Gidrogeokhimiya Rudnikh Elementov]; Nedra: Moscow, Russia, 1977; 216p. (In Russian)

61. Smedley, P.L.; Kinniburgh, D.G. Molybdenum in natural waters: A review of occurrence, distributions and controls. Appl. Geochem. 2017, 84, 387-432. [CrossRef]

62. Trivedi, P.; Axe, L. A Comparison of strontium sorption to hydrous aluminum, iron, and manganese oxides. J. Colloid Interface Sci. 1999, 218, 554-563. [CrossRef]

63. Pokrovsky, O.S.; Schott, J.; Dupre, B. Trace element fractionation and transport in boreal rivers and soil porewaters of permafrost-dominated basaltic terrain in Central Siberia. Geochim. Cosmochim. Acta 2006, 70, 3239-3260. [CrossRef]

64. Xue, H.B.; Kistler, D.; Sigg, L. Competition of copper and zinc for strong ligands in a eutrophic lake. Limnol. Oceanogr. 1995, 40, 1142-1152. [CrossRef]

65. Mackin, J.E.; Aller, R.C. Processes affecting the behavior of dissolved aluminum in estuarine waters. Mar. Chem. 1984, 4, 213-232. [CrossRef]

66. Nayyeri, H.; Zandi, S. Evaluation of the effect of river style framework on water quality: Application of geomorphological factors. Environ. Earth Sci. 2018, 77, 343. [CrossRef]

67. Afanasiev, A.N. The Water Resources and Water Balance of the Lake Baikal Watershed [Vodnye Resursi I Vodniy Balans Basseina Ozera Baikal]; Nauka: Novosibirsk, Russia, 1976; 238p.

(C) 2019 by the authors. Licensee MDPI, Basel, Switzerland. This article is an open access article distributed under the terms and conditions of the Creative Commons Attribution (CC BY) license (http://creativecommons.org/licenses/by/4.0/). 